Gia. 2007; 4: 15-24.

4. In Choi C, Baek DH, Lee SH, et al. Comparison Between Billroth-II with Braun and Roux-en-Y Reconstruction After Laparoscopic Distal Gastrectomy. J Gastrointest Surg. 2016;20(6): 1083-1090. doi:10.1007/s11605-016-3138-7.

5. Cui L-H, Son S-Y, Shin H-J, et al. Billroth II with Braun Enteroenterostomy Is a Good Alternative Reconstruction to Roux-en-Y Gastrojejunostomy in Laparoscopic Distal Gastrectomy. Gastroenterol Res Pract.
2017;27(7):1803851. doi:10.1155/2017/1803851

6. So JB-Y, Rao J, Wong AS-Y, et al. RouX-en-Y or Billroth II Reconstruction After Radical Distal Gastrectomy for Gastric Cancer: A Multicenter Randomized Controlled Trial. Ann Surg. 2018;267(2):236-242. doi:10.1097/SLA.0000000000002229.

7. Gustavsson S, Ilstrup DM, Morrison P, Kelly KA. Roux-Y stasis syndrome after gastrectomy. Am J Surg. 1988;155(3):490-494. doi:10.1016/ s0002-9610(88)80120-x.

\title{
ĐÁNH GIÁ KẾT QUẢ PHẪU THUÂT NộI SOI ĐƯờNG NÁCH VÚ TRONG ĐIỀU TRI U TUYẾN GIÁP LÀNH TÍNH TẠI BỆNH VIỆN ĐẠI HỌC Y HÀ NộI
}

\section{TÓM TẮT}

Mục tiêu: Đánh giá kết quả phẫu thuật nội soi đường nách vú trong điều tri u tuyến giáp lành tính tai Bệnh viện Đại học Y Hà Nội. Đối tượng và phương pháp: Nghiển cứu mô tả hồi cứu - tiến cứu trên 33 bệnh nhân chẩn đoán u tuyến giáp lành tính được phẫu thuât nội soi tai Bênh viên Đai hoc Y Hà Nôi từ 06/2020 đến 06/2021. Kết quả: Trung bình là 33,8 9,8 tuổi, $100 \%$ nữ giới; tỷ lể 1 u trên lâm sàng $84,8 \%$, $u$ thùy phải $59,0 \%$, kích thước u trung bình $25,4 \pm 12,3 \mathrm{~mm}$. Trên siêu âm, u TIRADS 3 chiếm $66,7 \%$. Giải phẫu bệnh sau mổ bướu giáp keo chiếm $72,7 \%$. Cắt thuỳ tuyến giáp ở $97 \%$ trường hợp. Thời gian mổ trung bình $45 \pm 7$ phút; thời gian hẩu phẫu $5 \pm 0,9$ ngày. Nói khàn tạm thời chiếm $3 \%$; tê bì, giảm cảm giác da chiếm $12,1 \%$. 94\% phấu thuật được xếp loại tốt, $97 \%$ bênh nhân đánh giá hài lòng về kết quả phẫu thuật. Kết luận: Phẫu thuật nội soi đường nách vú trong điều trị u tuyến giáp lành tính tương đối an toàn, tỷ lệ tai biến, biến chứng thấp và đạt thẩm mỹ cao.

Từ khóa: U giáp trạng, phẫu thuật nội soi.

\section{SUMMARY}

\section{RESULTS OF ENDOSCOPIC THYROIDECTOMY} VIA UNILATERAL AXILLO-BREAST APPROACH IN TREATMENT OF BENIGN THYROID NODULE AT HANOI MEDICAL UNIVERSITY HOSPITAL

Objective: Evaluate the early results of endoscopic thyroidectomy via unilateral axillo-breast approach (UABA) in the treatment of benign thyroid tumor at Hanoi Medical University Hospital. Subjects and Methods: Descriptive retrospective studies 33 patients with benign thyroid tumors were treated by UABA at Hanoi Medical University Hospital from $6 / 2020$ to 06/2021. Results: Mean of age was $38.2 \pm 9.8$ years. All patients were female. The solitary

*Bênh viên Đai hơc Y Hà Nôi

Chịu trách nhiệm chính: Nguyễn Xuân Hậu

Email: nguyenxuanhau@hmu.edu.vn

Ngày nhận bài: 18.6.2021

Ngày phản biên khoa hoc: 16.8.2021

Ngày duyệt bài: 23.8.2021

\section{Nguyễn Xuân Hậu*, Nguyễn Xuân Hiền*}

tumor occults $93.3 \%$, the thyroid tumors in the right lobe were $59,0 \%$, the average tumor size was $25.4 \pm 12.3 \mathrm{~mm}$. The tumors classified into TIRADS 3 by ultrasound was $66,7 \%$. Most common pathology was colloid goitre accounting for $72,7 \%$. Lobectomy was applied in $97 \%$ cases. The mean operating time was $45 \pm 7$ minutes, the mean hospitalization was $5 \pm 0.9$ days. The hoarseness was presented in 1 patient $(3 \%)$. A patient developed numbness in the anterior cervical region which occults $3 \%$. $94 \%$ cases were calssified into good group and $97 \%$ patients were satisfied with cosmetic outcomes of UABA. Conclusions: Endoscopic thyroidectomy via unilateral axillo-breast approach was safe, and achived good cosmetic outcomes.

Key words: Thyroid nodule, endoscopy thyroidectomy, UABA.

\section{I. ĐĂT VẤN ĐỀ}

U giáp trạng là bệnh lý phổ biến nhất của tuyến nội tiết. Theo tổ chức y tế thế giới, tỷ lệ mắc u giáp trạng là $12 \%$. Nữ giới có tỷ lệ mắc bênh cao hơn nam giới, tỷ lệ nữ/ nam là 4/1. Chẩn đoán dựa vào lâm sàng kết hợp với siêu âm vùng cổ và chọc hút tế bào bằng kim nhỏ khối u.

Phẫu thuật là phương pháp quan trọng nhất điều trị khối u giáp trạng. Hiện nay có hai phương pháp phẫu thuật là mổ mở và mổ nội soi. Trong đó, phẫu thuật nội soi ngày càng được áp dung rông rãi.

Tại Việt Nam, nhiều phương pháp phẫu thuật nội soi đã được áp dụng như phẫu thuật nội soi đường miêng, phâu thuât nôi soi đường nách vú. Phẫu thuật nội soi đường nách - vú với những ưu điểm riêng do đó ngày nay vẫn được áp dụng trong điêu trị bệnh lý u tuyến giáp. Chúng tôi tiến hành nghiên cứu này nhằm đánh giá kết quả phẫu thuật nội soi đường nách vú trong điều trị u tuyến giáp lành tính tại Bệnh viện Đại học Y Hà Nội. 
II. ĐỐI TƯỢNG VÀ PHƯƠNG PHÁP NGHIÊN CỨU

1. Đối tượng nghiên cứu. Gồm 33 bệnh nhân chẩn đoán u giáp trạng lành tính được phẫu thuật nội soi tuyến giáp tại Bệnh viện Đại học $Y$ Hà Nội. Thời gian thực hiện nghiên cứu từ tháng 6/2020 đến tháng 6 năm 2021.

1.1. Tiêu chuẩn chọn bệnh nhân.

- Bệnh nhân u tuyến giáp chẩn đoán trước mổ lành tính dựa vào siêu âm vùng cổ và tế bào học qua chọc hút bằng kim nhỏ (Chọc 2 lần, cách nhau ít nhất 1 tháng)

- Chọn u:

$\checkmark$ Trường hợp một u: Kích thước lớn nhất của $\mathrm{u} \leq 5 \mathrm{~cm}$.

$\checkmark$ Trường hợp nhiều u: Các u ở một thùy hoặc một thùy và eo giáp, kích thước thùy giáp $<6 \mathrm{~cm}$.

\subsection{Tiêu chuẩn loại trừ:}

- Tiền sử phẫu thuật, xạ trị vùng cổ.

- Tình trạng viêm cấp tính toàn thân hoặc tại tuyến giáp, tuyến vú bên phẫu thuật.

- Có chống chỉ đinh chung của phẫu thuât, gây mê hồi sức: bất thường chúc năng đông máu, bệnh mạn tính toàn thân, thể trạng kém.

2. Phương pháp nghiên cứu: Nghiên cứu mô tả hồi cứu

\section{Phương pháp thu thập số liệu}

3.1. Đặc điểm lâm sàng: Tuổi; giới; lý do vào viện; khám u: vị trí u (thùy phải, thùy trái, eo), số lượng $u$, kích thước $u(\mathrm{~cm})$, mật độ u (mềm hay cứng, chắc), ranh giới u (rõ hay không rõ), di động u (có hay không có di động).

3.2. Cận lâm sàng: Siêu âm tuyên giáp đánh giá: số lượng u, phân loại TIRADS; vị trí u (thùy phải, thùy trái, eo), kích thước $u$.

\subsection{Phương pháp phẫu thuật nội soi} tuyến giáp đường nách vú 1 bên

$\checkmark$ Phương pháp vô cảm: mê nội khí quản

$\checkmark$ Dụng cụ phẫu thuật: Dàn máy nội soi, dụng cụ nội soi, dao siêu âm nội soi, dao điện.

$\checkmark$ Tư thế bệnh nhân: Bệnh nhân nằm ngửa, kê gối vai ngửa cổ tối đa, cổ quay về phía thùy giáp lành. Tay cùng bên dạng tối đa để bộc lộ rõ vùng hố nách, tay đối diện dạng vuông góc thân mình.

$\checkmark$ Các bước phẫu thuật:

- Đắt troca: Troca 10 được đặt tại đường nách giữa mang với bờ trên tuyến vú, 1 troca 5 đặt ở rãnh delta ngực cùng bên, 1 troca 5 đặt ở quầng vú cùng bên.

- Taoo khoang phẫu thuật: Dùng đơn cực bóc tách lớp dưới da vùng ngực đến vùng cổ đến ngang sụn giáp, sang hai bên đến cơ ức đòn chũm.

- Tách cơ vào tuyến giáp: Tách bờ trước cơ ức đòn chũm ra ngoài, cơ vai móng lên trên ra ngoài, tách dọc cơ ức giáp để vào tuyến giáp.

- Đánh giá tổn thương để đưa ra hướng phẫu thuật: Cắt thùy giáp, lấy u giáp trạng, cắt thuỳ và eo tuyến giáp.

- Chú ý trước khi cắt thùy giáp bộc lộ rõ thần kinh quăt ngược và tuyến cận giáp để bảo tồn.

- Kiểm tra và lấy bê̂nh phẩm

$\checkmark$ Các chỉ số phấu thuật: Thời gian phẫu thuật, thời gian hậu phẫu, số ngày rút dẫn lưu; tai biến, biến chứng: khàn tiếng, chảy máu, tê bì vùng ngực, nhiễm trùng. Đánh giá kết quả sau 1 tháng.

\section{KẾT QUẢ NGHIÊN CỨU}

\section{1. Đặc điểm lâm sàng, cận lâm sàng.} Tuổi

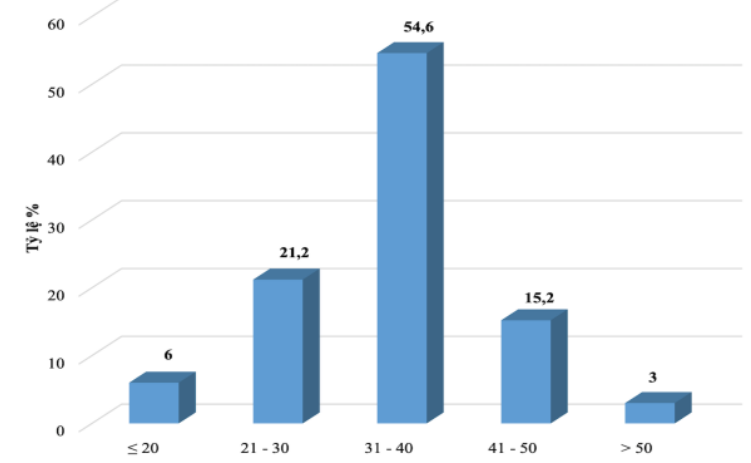

Biểu đồ 1. Phân chia nhóm tuổi

Tuổi trung bình là $34,5 \pm 9,8$ tuổi, nhóm 31 40 tuổi hay gặp nhất chiếm $54,6 \%$

Giới: Tất cả bệnh nhân đêu là nữ giới

Lý do vào viện: Sờ thấy u hay gặp nhất $69,7 \%$.

Đặc điểm u trên lâm sàng: 93,9\% số bệnh nhân khám có thể sờ thây u trên lâm sàng. Trong số các bệnh nhân này, tất cả các u sờ thấy đều có mật độ mềm, ranh giới rõ với xung quanh và di động theo nhịp nuốt.

\section{Siêu âm}

Bảng 1. Đặc điểm u qua siêu âm

\begin{tabular}{|c|c|c|c|}
\hline \multicolumn{2}{|c|}{ Đặc điểm u } & Số u & Tỷ lệ \% \\
\hline \multirow{3}{*}{ Vị trí } & Thù̀y trái & 15 & 38,5 \\
\cline { 2 - 4 } & Thùy Phải & 23 & 59,0 \\
\cline { 2 - 4 } & Eo & 1 & 2,5 \\
\hline \multicolumn{2}{|c|}{ Tống } & $\mathbf{3 9}$ & $\mathbf{1 0 0}$ \\
\hline \multirow{2}{*}{$\begin{array}{c}\text { Thành } \\
\text { phần }\end{array}$} & Dịch & 11 & 28,2 \\
\cline { 2 - 4 } & Hôn hợp & 20 & 51,3 \\
\cline { 2 - 4 } & Đặc & 8 & 20,5 \\
\hline \multicolumn{2}{|c|}{ Tống } & $\mathbf{3 9}$ & $\mathbf{1 0 0}$ \\
\hline
\end{tabular}

Về số lượng u: số bệnh nhân có một u chiếm $84,8 \%$, trái lại, bệnh nhân đa u chiếm $15,2 \%$. Về phân loại TIRADS 2011, các khối u xếp loại TIRADS 3 chiếm tỷ lệ $66,7 \%$; các khối u xếp loại 
TIRADS 4a chiếm 24,2\%. Về kích thước u: kích

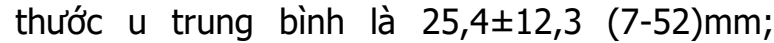
nhóm u có kích thước từ 2 đến $4 \mathrm{~cm}$ chiếm tỷ lệ cao nhất 19/39, chiếm 48,7\%.

\section{2. Điêu trị}

Thời gian và phương pháp phẫu thuât. Thời gian mổ trung bình là 45,5 7 (40-65) phút

Bảng 2. Phương pháp phẫu thuât

\begin{tabular}{|c|c|c|c|}
\hline \multirow{2}{*}{ PPPT } & & $\mathbf{n}$ & Tỷ lệ (\%) \\
\cline { 2 - 4 } & Cắt thùy & 32 & 97 \\
\cline { 2 - 4 } & Cắt thùy và eo & 1 & 3 \\
\hline
\end{tabular}

Thời gian năm viện và rút dân lưu

Bảng 3. Thời gian rút dấn Iưu và nằm viện

\begin{tabular}{|c|c|c|c|}
\hline Tham số & $\begin{array}{c}\text { Trung } \\
\text { bình }\end{array}$ & $\begin{array}{c}\text { Giá trị } \\
\text { nhò } \\
\text { nhất }\end{array}$ & $\begin{array}{c}\text { Giá trị } \\
\text { Iớn } \\
\text { nhất }\end{array}$ \\
\hline Ngày dần lưu & $4,8 \pm 0,9$ & 3 & 7 \\
\hline Ngày nằm viện & $5,0 \pm 0,9$ & 3 & 7 \\
\hline
\end{tabular}

Kết quả phẫu thuật

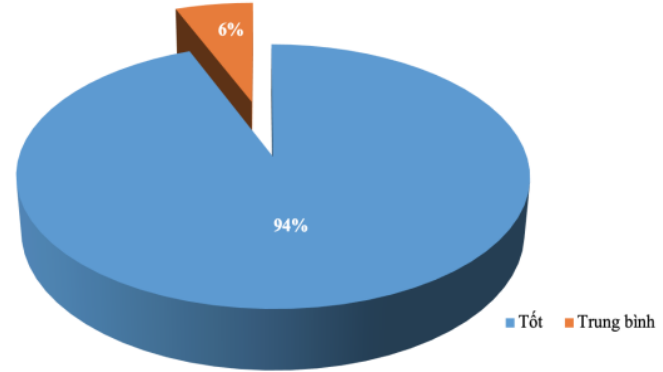

Biểu đồ 2. Kêt quả phẫu thuật Bảng 4. Biến chứng sau phẫu thuật

\begin{tabular}{|c|c|c|}
\hline Triệu chứng & $\begin{array}{c}\text { Số bệnh } \\
\text { nhẩn }\end{array}$ & $\begin{array}{c}\text { Tỷ lệ } \\
\text { (\%) }\end{array}$ \\
\hline Khàn tiếng tạm thời & 01 & 3 \\
\hline Hạ canxi huyết & 0 & 0 \\
\hline Nuốt vướng & 01 & 3 \\
\hline Tê bì, giảm cảm giác da & 4 & 12,1 \\
\hline
\end{tabular}

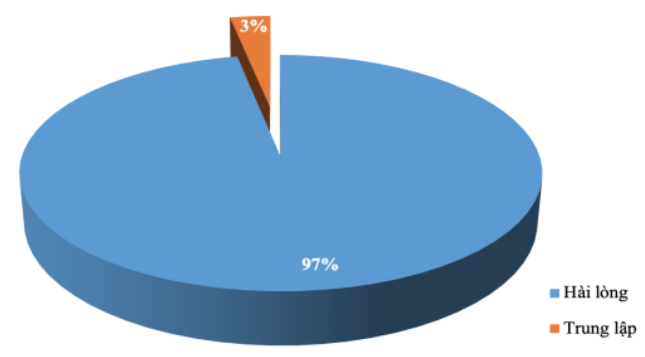

Biểu đồ 3. Mức độ hài lòng thẩm mỹ sau mổ

\section{BÀN LUÂ̂N}

4.1. Đăc điểm lâm sàng, cân lâm sàng

Tuổi, giới. Trong nghiên cứu của chúng tôi tuổi trung bình $34,46 \pm 9,8$ tuổi, nhỏ nhất là 20 tuổi và cao nhất là 54 tuổi. Kết quả này thấp hơn với nghiên cứu của Lê Văn Quảng (2001), lứa tuổi 21-60 tuổi là 76,6\% [1]. Có thể giải thích cho sự khác nhau này là do trong nghiên cứu của chúng tôi lựa chọ bênh nhân trẻ tuổi, nhu cầu thẩm mỹ cao đảm bảo vai trò nổi trội của phẫu thuật nội soi.

Tỷ lệ nữ trong nghiên cứu của chúng tôi tất cả bệnh nhân đều là nữ giới. Kết quả này cũng giống nghiên cứu của Nguyễn Quốc Bảo (2010), tỉ lệ ung thư giáp trạng ở nam giới khoảng 1,8/100.000 dân, ở nữ khoảng 5,6/100.000 dân [2]. Nghiên cứu của Lê Văn Quảng (2002), tỷ lệ nứ/nam là 2,5/1[1]. Các nghiên cứu nước ngoài cũng cho thấy tỷ lệ nữ mắc bệnh cao hơn như tại Hàn Quốc trên 1616 trường hợp chỉ có 71 trường hợp là nam giới [3]. Trong 173 trường hợp mố nội soi tuyến giáp đầu tiên tại bệnh viện nội tiết trung ương chỉ có 10 bệnh nhân nam [4].

Triệu chứng lâm sàng. Đa số bệnh nhân đến viện với lý do xuất hiện u giáp đơn thuần chiếm tỷ lệ cao nhất $(69,7 \%)$, kết quả này tương tự nghiên cứu của Lê Văn Quảng (2002) trên 308 bênh nhân ung thư giáp trang được điều trị tại Bệnh viện $K$, có $68,5 \%$ trường hợp là triệu chứng u giáp. Theo tác giả Hershman và Blahd (2005), tỉ lệ bệnh nhân đến viện có tới 15,2\% là chỉ tình cờ phát hiện qua khám sức khỏe.

Trong nghiên cứu của chúng tôi, 93,9\% bệnh nhân có u giáp trên lâm sàng. Kết quả của chúng tôi tương tự nghiên cứu của tác giả Đinh Xuân Cường (2010) là 96,4\% [5].

Siêu âm tuyến giáp. Trong nghiên cứu của chúng tôi siêu âm phát hiện được $100 \%$ có u tuyến giáp, trong đó tỷ lệ một u đơn độc là $84,8 \%$. Tỷ lê găp u ở thùy phải nhiều nhất chiếm $59 \%$. Kích thước u trung bình trong nghiên cứu của chúng tôi là $25,4 \pm 12,3 \mathrm{~mm}$. Hiện nay, tại Bênh viện Đại hoc $Y$ Hà Nội đang áp dụng phương pháp đánh giá kết quả siêu âm tuyến giáp theo TIRADS, trong nghiên cứu của chúng tôi tỷ lệ gặp nhiều nhất là TIRADS 3 với $66,7 \%$. Dựa vào phân loại theo TIRADS, người ta ước tính được nguy cơ ác tính của khối u tuyến giáp (ví dụ: TIRADS 4a là $20 \%$, 4b là 40\%, 4c là 60\%...).

\subsection{Kết quả điêu trị}

Phương pháp phẫu thuật. Trong nghiên cứu của chúng tôi, phần lớn bệnh nhân được phẫu thuật cắt thùy giáp chứa khối u chiếm $97,0 \%$. Có 1 bênh nhân đước cắt thùy và eo giáp trạng. Sở dĩ chúng tôi phẫu thuật cắt cả eo tuyến giáp là do trong một số trường hợp u nằm ơ vị trí sát eo giáp trạng.

Thời gian phẫu thuật và thời gian hâu phẫu, thời gian rút dẫn lưu. Thời gian phầu 
thuật trung bình là 45,5 47 phút, thời gian hậu

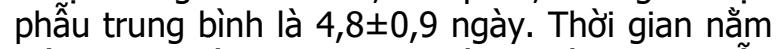
viện trung bình $5,0 \pm 0,9$ ngày. Thời gian phẫu thuật của chúng tôi cao hơn nghiên cứu của Trân Ngọc Lương [6] là 40 phút.

Biến chứng sau mổ. Trong nghiên cứu của chúng tôi có $3 \%$ bệnh nhân bị khàn tiếng tạm thời sau mổ. Ngoài ra có 1 bệnh nhân xuất hiện nuốt vướng sau mổ. 12,1\% bệnh nhân xuất hiện tê bì, giảm cảm giác da vùng cổ. Kết quả phẩu thuật tốt ở 94\% trường hợp, 97\% bệnh nhân hài lòng về kết quả thẩm mỹ sau mổ. Kết quả này cũng tương tự với các nghiên cứu trước đó của Trân Ngọc Lướng [6], Nguyễn Xuân Hậu [7].

\section{KẾT LUẬN}

Phẫu thuật nội soi đường nách vú trong điều trị u tuyến giáp lành tính tương đối an toàn, tỷ lệ tai biến, biến chứng thấp và đạt thẩm mỹ cao.

\section{TÀI LIỆU THAM KHẢO}

1. Lê Văn Quảng (2002). "Nhân xét đăc điểm lâm sàng và các phương pháp điểu trị ung thư tuyến giáp tại Bệnh viện K tứ năm 1992 - 2000". Tạp chí Y học, số (431), 323 - 326.
2. Nguyễn Quốc Bảo (2010). Ung thư tuyến giáp. Điểu trị phâuu thuật bệnh ung thư 2010. Nhà xuất bản y hoc, trang 92-113.

3. Bae, Gia Seong MD; Cho, Young Up MD, Sung, Gi Young MD et al (2008). The current status of endoscopic Thyroidectomy in Korea. Surgical laparoscopy, endoscopy and percutaneous techniques: June 2008-Volume 18- Issue 3-pp231-235.

4. Trân Ngọc Lương, Trân Đoàn Kết, Ta Văn Bình (2004). Phẩu thuât tuyến giáp bẳng kỹ thuật nội soi: một số nhận xét về kỹ thuật và chỉ định mổ. Tạp chí y học thực hành số 491/2004, trang 366-373.

5. Đinh Xuân Cường (2004). "Nghiên cứu đặc điểm lâm sàng, mô bênh học và kết quả điều trị phẫu thuật ung thư tuyến giáp tại bệnh viện $\mathrm{K}^{\prime \prime}$. Luân văn thạc sĩ y học, Hà Nối, $33-48$.

6. Trầ̆n Ngoc Lương (2011). Đánh giá kết quả phẩu thuậ̣t nội soi điêu trị bướu giáp lành tính. Tạp chí phẫu thuất nội soi và nội soi Việt Nam - tập 1 năm 2011, sổ 2 trang 20-24.

7. Nguyen X.H., Nguyen X.H., Mai T.K.N. và cộng sự. (2019). Feasibility and Safety of Endoscopic Thyroidectomy Via a Unilateral Axillobreast Approach for Unilateral Benign Thyroid Tumor in Vietnam. Surg Laparosc Endosc Percutan Tech, 29(6), 447-450.

\section{ĐÁNH GIÁ KẾT QUẢ HÓA TRI PHÁC ĐỒ Có PEMETREXED TRONG UNG THƯ PHỔI KHÔNG TẾ BÀO NHỎ GIAI ĐOẠN IIIB-IV TẠI BỆNH VIỆN BẠCH MAI}

\section{TÓM TẮT}

Mục tiêu: Đánh giá kết quả hóa trị phác đồ có Pemetrexed ở bệnh nhân ung phổi không tế bào nhỏ giai đoạn IIIB-IV tại Bệnh viện Bach Mai. Đối tượng và phương pháp nghiên cứu: Nighiên cứu mô tả hồi cứu kết hợp tiến cứu trên 63 bênh nhân ung thư biểu mô tuyến của phổi giai đoạn IIIBB-IV được điều trị hóa chất phác đồ có pemetrexed tại Bệnh viển Bạch Mai từ tháng 6/2018 đến tháng 6/2021. Kết quả: Tuổi trung bình: $61,5 \pm 7,2$; tuổi lớn nhất: 74 ; Tỷ lệ nam/nữ: $1,75 / 1 ; 76,3 \%$ bệnh nhân đạt được đáp ứng cơ năng; trong đó có $16,9 \%$ đáp ứng hoàn toàn; Đáp ứng thực thể: $38,1 \%$ đáp ứng một phân, $39,1 \%$ bệnh ổn định, 20,6\% bệnh tiến triển và có 1 bệnh nhân đáp ứng hoàn toàn; Trung vị thời gian sống không bênh tiến triển là 8,2 tháng (CI 95\%: 7,1-9,5); trung vị thời gian sống thêm toàn bộ là 16,0 tháng; (CI 95\%: 14,2 -

*Trung tâm Y học hạt nhân và Ung bướu, Bệnh viện Bach Mai

Chịu trách nhiệm chính: Lê Viết Nam

Email: vietnamhmu@gmail.com

Ngày nhận bài: 18.6.2021

Ngày phản biên khoa hoc: 17.8 .2021

Ngày duyệt bài: 24.8.2021

\section{Lê Viết Nam*, Phạm Cẩm Phương*}

17,8); Tình trang toàn thân theo ECOG tốt cải thiện tỷ lệ đáp ứng, kéo dài thời gian sống thêm không bệnh tiến triển và thời gian sống thêm toàn bộ. Kết luận: Điều tri ung thư phổi loai biểu mô tuyển giai đoạn IIIB-IV bằng phác đồ hóa chất có pemetrexed giúp cải thiện tỷ lệ đáp ứng và thời gian sông thêm. nhỏ

Tư khóa: Pemetrexed, ung thư phổi không tế bào

\section{SUMMARY}

\section{EVALUATING THE RESULTS OF CHEMOTHERAPY WITH PEMETREXED REGIME IN STAGE IIIB-IV NON-SMALL CELL LUNG CANCER AT BACH MAI HOSPITAL}

Objective: To evaluate the results of chemotherapy with pemetrexed in stage IIIB-IV nonsmall cell lung cancer at Bach Mai Hospital. Subjects and Methods: $A$ retrospective and prospective descriptive study on 63 adenocarcinoma lung cancer patients with stage IIIB-IV who received chemotherapy with pemetrexed at Bach Mai Hospital since June 2018 to June 2021. Results: Mean age: $61.5 \pm 7.2$; the oldest patient: 74 ; male/female ratio: $1.75 / 1 ; 76,3 \%$ of patients achieve clinical symptoms response; of which $16,9 \%$ respond completely; Ratio 